\title{
From continent to intra-oceanic arc: Zircon xenocrysts record the crustal evolution of the Solomon island arc
}

\author{
Simon Tapster ${ }^{1,2}$, N.M.W. Roberts ${ }^{2}$, M.G. Petterson 1 , A.D. Saunders ${ }^{1}$, and J. Naden ${ }^{3}$ \\ 'Department of Geology, University of Leicester, Leicester LE1 7RH, UK \\ 2NERC Isotope Geosciences Laboratory, British Geological Survey, Keyworth, Nottingham NG12 5GG, UK \\ ${ }^{3}$ British Geological Survey, Keyworth, Nottingham NG12 5GG, UK
}

\section{ABSTRACT}

The first U-Pb ages from a ca. 26-24 Ma pluton on Guadalcanal, in the intra-oceanic Solomon island arc (southwest Pacific Ocean), reveal Eocene- to Archean-aged zircon xenocrysts. Xenocryst populations at ca. 39-33 Ma and ca. 71-63 Ma correlate with previously obtained ages of supra-subduction magmatism within the arc. A ca. 96 Ma zircon population may be derived from Cretaceous ophiolite basement crust or region-wide continental rift-related magmatism. Xenocryst age populations alternate with periods of oceanic basin formation that fragmented the East Gondwana margin. Early Cretaceous to Archean zircon xenocryst ages imply continental origins and a cryptic source within the arc crust; they may have been introduced by Eocene interaction of a continental fragment with the arc, and concealed by ophiolite obduction. The data demonstrate that continentally derived zircons may be transported thousands of kilometers from their source and added to intra-oceanic arc magmas, a process likely facilitated by cyclical subduction zone advance and retreat. The findings highlight the continuum of arcs that occurs between continental and oceanic end members, and the caution with which zircons should be used to determine the provenance and setting of ancient arc terranes accreted to the continental crust.

\section{INTRODUCTION}

The accretion of intra-oceanic arcs (IOAs) to the continents is demonstrated by the juxtaposition of diachronous terranes containing ophiolites, oceanic arc-affinity plutons, and volcano-sedimentary rocks. Zircon's robust $\mathrm{U}-\mathrm{Pb}$ chronometer and refractory nature establishes it as a frequently used tool for determining the provenance of arc terranes and reconstructing the growth of their associated orogens. However, xenocrystic zircons derived from unobserved continental sources have been documented in ancient and characteristically IOA terranes (Kröner, 2010). While regions such as the Arabian-Nubian Shield represent some of the largest additions of IOA juvenile crust to the continents, the presence of enigmatic zircon xenocrysts (e.g., Hargrove et al., 2006) is problematic for interpreting the real contributions of IOAs to the evolution of continents (Condie and Kröner, 2013). Examples of continentderived zircon in modern IOAs are scarce, and our understanding of how this material may be introduced into the arc setting is poor.

The Solomon island arc (SIA) defines a major zone of active convergence between the Indo-Australian and Pacific plates (Fig. 1A). Seismological estimates of the SIA's crustal thickness and bulk composition are comparable with those of the Izu-Bonin IOA (Miura et al., 2004). Prior to this study, no continental material had been documented in the SIA, and the oldest basement lithology was a $92 \pm 20 \mathrm{Ma}$ normal mid-ocean-ridge basalt type ophiolite (Petterson et al., 1999). Along strike of the southwest Pacific convergent zone, arcs have evolved within an extensional accretionary orogen setting (Collins, 2002), whereby periodic episodes of Pacific slab retreat, and extension of the East Gondwana continent margin, generated continental rift-related magmatism (135-80 $\mathrm{Ma}$ ), micro-continental blocks, and extensive back-arc basins (Bryan et al., 1997; Crawford et al., 2003; Schellart et al., 2006). Previous tectonic reconstructions have extrapolated an extensional continent-margin setting to the early SIA (Schellart et al., 2006); others have sug- gested IOA origins on the Pacific plate (Yan and Kroenke, 1993) and predicted later continentmargin interaction (Hall, 2002).

We document the first $\mathrm{U}-\mathrm{Pb}$ geochronology and evidence for continental material within the crust of Guadalcanal, SIA. Here, an Oligoceneaged pluton contains a complex record of zircon xenocryst ages, which, when integrated with other regional data from the southwest Pacific extensional accretionary orogen, gives a new geodynamic context for the evolution of crustal components. Furthermore, the work offers valuable insights into the interpretation of tectonic processes that incorporate continentally derived zircon into ancient IOA terranes.

\section{SIA REGIONAL GEOLOGY AND TECTONICS}

The SIA is a complex crustal collage. Late Cretaceous ophiolite units form the basement of Choiseul, Florida, and Guadalcanal Islands (Fig. 1). The Jajao igneous suite (ca. 68-62 and 46 Ma; Tejada et al., 1996) is the oldest arcback-arc unit, previously inferred as an exotic IOA (Yan and Kroenke, 1993) associated with northeast-dipping subduction beneath the Pacific plate (Hall, 2002). Following the Eocene shearing of Cretaceous ophiolite basement (Fig. 1C;

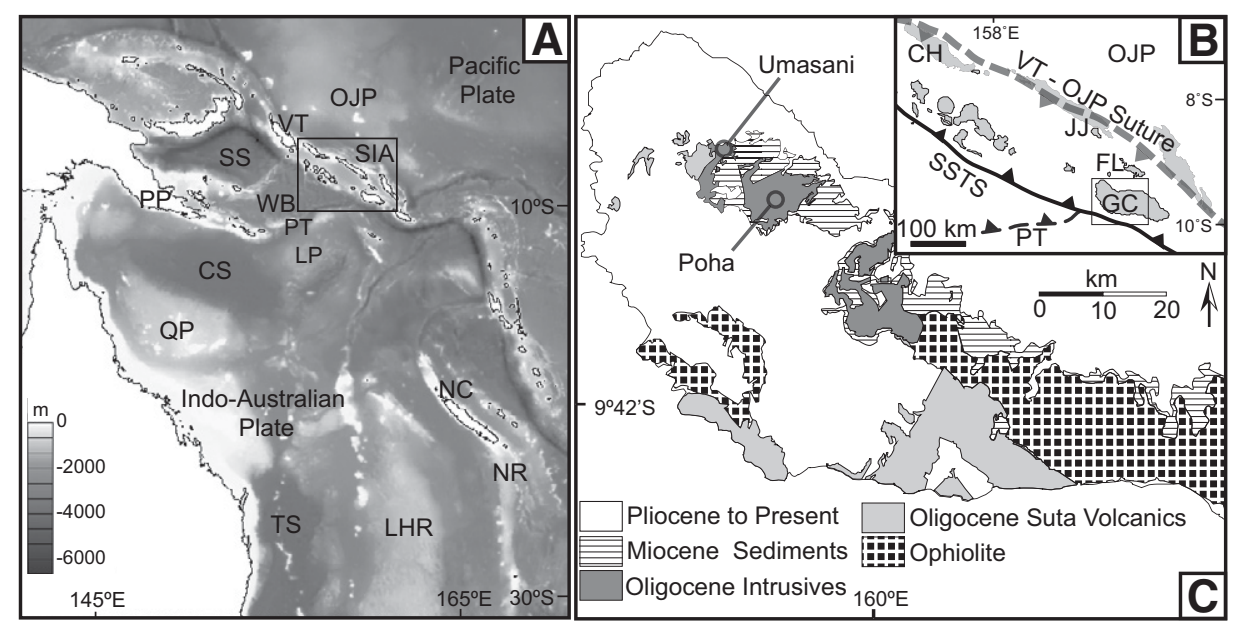

Figure 1. A: Present-day southwest Pacific Ocean bathymetry (www.geomapapp.org). B: Tectonic map of present-day Solomon island arc. C: Simplified lithology of Guadalcanal (after Hackman, 1980). CH-Choiseul Island; CS-Coral Sea; FL-Florida Islands; GC-Guadalcanal; JJ-Jajao igneous suite; LHR-Lord Howe Rise; LP-Louisiade Plateau; NC-New Caledonia; NR-Norfolk Ridge; OJP_Ontong Java Plateau; PP-Papuan Peninsula; PTPocklington Trough relict subduction zone; QP-Queensland Plateau; SIA-Solomon island arc; SS-Solomon Sea; SSTS-South Solomon Trench System; TS-Tasman Sea; VT-Vitiaz Trench; WB-Woodlark Basin (younger than $6 \mathrm{Ma}$ and currently subducting at the SSTS). 
Geology, published online on 24 October 2014 as doi:10.1130/G36033.1

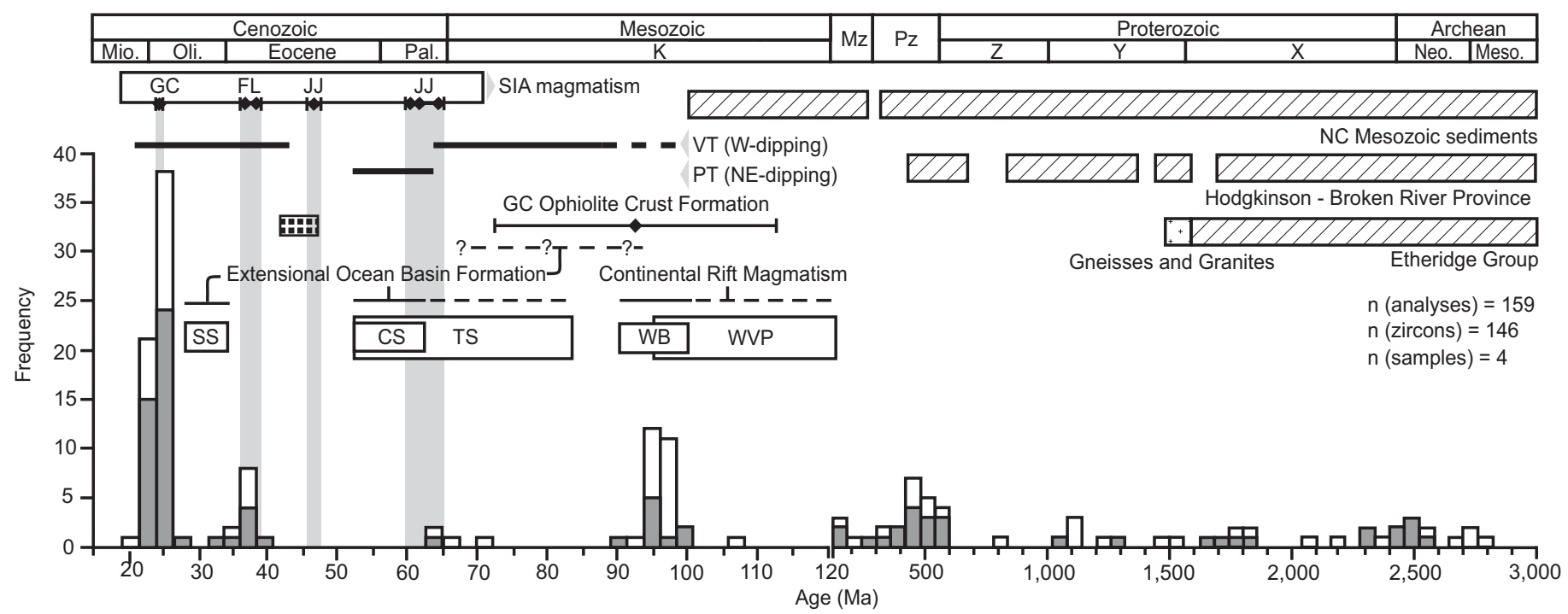

— Active Subduction Zone $\square$ Concordant Dates $\square$ Discordant Dates $\mathrm{H}$ Ar-Ar + K-Ar Dates (Literature) $\square$ Detrital Zircons (Literature) 世田 GC Ophiolite Deformation

Figure 2. Frequency histogram of zircon dates from the Umasani pluton and summary of corresponding regional tectonic events and zircon ages; xenocryst ages older than $120 \mathrm{Ma}$ compare with northeast Australian and New Caledonian detrital zircon populations; zircon dates and overlapping magmatic arc units alternate with periods of basin formation and ophiolite crustal genesis since the Late Cretaceous continental rifting events. Mio.-Miocene; Oli.-Oligocene; Pal.-Paleocene; Mz-Mesozoic; Pz-Paleozoic; WVP-Whitsunday volcanic province; other abbreviations as in Figure 1. Concordant ages have $>90 \%$ concordance, discordant ages $<90 \%$ concordance. Histogram bins $<120$ Ma represent $2 \mathrm{~m}$.y.; $>120 \mathrm{Ma}$ bins represent $60 \mathrm{Ma} .{ }^{206} \mathrm{~Pb} /{ }^{238} \mathrm{U}$ ages are used for $<600 \mathrm{Ma},{ }^{207} \mathrm{~Pb} /{ }^{206} \mathrm{~Pb}$ ages for older zircons. Data and references are given in Figure DR2 and Table DR2 (see footnote 1).

Hackman, 1980), mid-late Eocene gabbro-tonalite emplacement (Neef and McDougall, 1976), and the 34-28 Ma opening of the Solomon Sea backarc basin (Joshima et al., 1986) indicate the onset of SIA growth related to southwestdirected Pacific plate subduction at the Vitiaz Trench, which continued until the collision of the Ontong Java Plateau (Petterson et al., 1999; Hall, 2002). Intrusive silicic magmatism is expressed on Guadalcanal as the Oligocene Umasani, Poha, and Lungga plutonic complexes (Hackman, 1980), and is temporally constrained by an early Miocene unconformity and a single 24.4 $\mathrm{Ma}(\mathrm{K}-\mathrm{Ar})$ age from the Poha complex (Chivas and McDougall, 1978). The late Miocene reversal of subduction zone polarity (Petterson et al., 1999) consumed much of the Solomon Sea at the northeast-dipping South Solomon Trench System, juxtaposing the Louisiade Plateau, arguably a fragment of continental crust (Gaina et al., 1999), against the arc.

\section{OLIGOCENE INTRUSIVE AGES}

In this study, we focus on the geochronological record contained within a tonalite (X008) and three representative diorites (X002, UM13B, UM14B; Table DR1 in the GSA Data Repository $^{1}$ ) of the $20 \mathrm{~km}^{2}$ Umasani plutonic complex (Fig. 1C). Sample descriptions, methodology, representative zircon cathodoluminescence images, and isotopic data are provided in the Data Repository. The U-Pb data obtained through laser ablation inductively coupled plasma mass spectrometry are summarized in Figure 2. Zircon morphologies and internal textures are variable (Fig. DR1 in the Data Repository); irregular and prismatic morphologies range up to $200 \mu \mathrm{m}$ in length and are typically $<100 \mu \mathrm{m}$ in width, while rounded crystals do not exceed diameters of $50 \mu \mathrm{m}$.

Average ages of the youngest analyses (Fig. DR3 and Table DR2) are 23.3 $\pm 3 \mathrm{Ma}(\mathrm{UM} 13 \mathrm{~B}$; $\mathrm{n}=4), 24.5 \pm 1 \mathrm{Ma}(\mathrm{UM} 14 \mathrm{~B} ; \mathrm{n}=18)$ and 24.2 $\pm 1.4 \mathrm{Ma}(\mathrm{X} 008 ; \mathrm{n}=39)$; $\mathrm{U}-\mathrm{Pb}$ analysis of rutile from UM13B gives a similar age of $23.5 \pm 3.3$ Ma. Diorite X002 yielded a U-Pb titanite age of $25.7 \pm 0.9 \mathrm{Ma}$, but no Oligocene zircons. Given the early Miocene stratigraphic constraints and 24.4 Ma K-Ar age of the Poha complex, the data are interpreted as recording late Oligocene intrusion ages.

\section{ZIRCON XENOCRYST AGES AND PROVENANCE}

In addition to late Oligocene zircons, the data indicate xenocrystic zircon components ranging from 2752 to $33 \mathrm{Ma}$ (Fig. 2; Fig. DR3). While the environment of zircon genesis is not constrainable from age alone, the populations at 39-33 Ma $(\mathrm{n}=12)$ and 71-63 Ma $(\mathrm{n}=4)$ are coeval with earlier arc-related magmatic units (Fig. 2) within the SIA, which implies zircon recycling from older arc crust. Eocene-aged rims around Mesozoic- and Cambrian-aged inherited cores were identified in two zircons grains (Fig. DR1).

A single population at $95.8 \pm 4.1 \mathrm{Ma}$ is present in UM13B ( $n=25)$ and X002 $(n=2)$ (Fig. 2; Fig. DR3). Coeval centers of magmatism related to continental breakup are prevalent across the East Gondwana margin, including the 132-95 Ma Whitsunday volcanic province (Bryan et al., 1997) and a probable expression in the basement of the Woodlark Basin Rift at 100-90 Ma (Zirakparvar et al., 2013; Fig. 3). Magmatism of continental rift affinity is located on New Caledonia at ca. $88 \mathrm{Ma}$ and was preceded by ca. 102 Ma arc activity (Nicholson et al., 2011). The ca. 92 Ma Guadalcanal ophiolite also offers a possible coeval, albeit poorly constrained, local source for assimilation, although no zircon has yet been documented from this ophiolite.

Paleozoic to Archean zircon dates (266-2752 $\mathrm{Ma} ; \mathrm{n}=57$ ) imply derivation from a continental source. The closest known Archean terrane is $>1000 \mathrm{~km}$ inland from the present east coast of Australia. However, Baldwin and Ireland (1995) identified a ca. $2781 \mathrm{Ma}$ zircon population in clasts from the Woodlark Basin Rift system; no protolith was identified, but reworked Archean crust was predicted elsewhere within the region. Comparable age spectra to $>95$ Ma xenocrysts are found within New Caledonian Mesozoic sed-

${ }^{1}$ GSA Data Repository item 2014372, methods, Table DR1 (sample descriptions), Table DR2 (U-Th-Pb data), Figure DR1 (zircon cathodoluminescence images), Figure DR2 (expanded figure caption and references for Fig. 2), and Figure DR3 (U-Pb zircon, titanite, and rutile age plots, individual sample frequency histograms), is available online at www.geosociety.org/pubs/ft2014.htm, or on request from editing@ geosociety.org or Documents Secretary, GSA, P.O. Box 9140, Boulder, CO 80301, USA. 

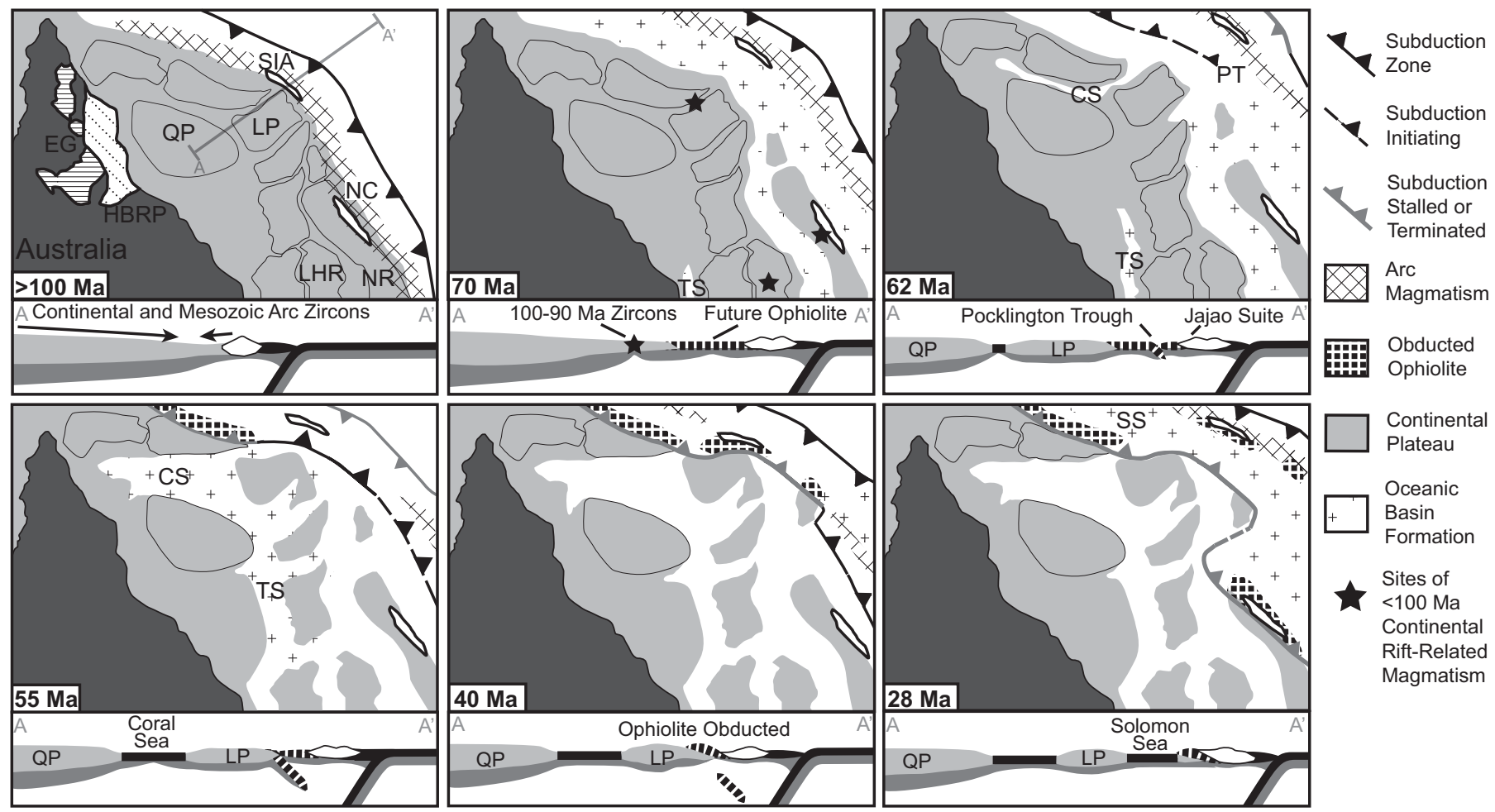

Figure 3. Schematic reconstruction of East Gondwana fragmentation and Solomon island arc (SIA) crustal evolution from $>100$ Ma to 28 $\mathrm{Ma}$ (modified from Schellart et al., 2006; Whattam et al., 2008). Continental rift-related zircons (100-90 Ma) located in Woodlark Basin Rift basement are proximal to Archean clasts (see text). EG-Archean zircon-bearing sources of the Etheridge group; HBRP-HodgkinsonBroken River province; other abbreviations as in Figure 1.

iments (Fig. 2; Adams et al., 2009). Adams et al. (2009) proposed that Archean to early Paleozoic zircon was reworked from continental metasediments of the Etheridge group and HodgkinsonBroken River province, northeast Queensland, Australia, and that Mesozoic zircon was derived from East Gondwanan marginal arcs (Fig. 3; Fig. DR2). The continental and Triassic to early Cretaceous zircon xenocrysts $(n=4$; Fig. 2 ) suggest that a continent-margin depositional center, bounded by Mesozoic continental arcs similar to that of New Caledonia, contributed zircon to the SIA crust.

\section{TECTONIC EVOLUTION OF THE SIA CRUST}

The presence of Paleozoic and older zircons provides the first direct evidence of the presently intra-oceanic SIA's association with continental crust, and requires the SIA's tectonic evolution to be evaluated in the context of regional events.

Figure 2 illustrates that zircon populations and correlating magmatic arc units are punctuated by periods of oceanic basin opening and the formation and deformation of ophiolitic crust. The Late Cretaceous breakup of the East Gondwana margin and initiation of the southwest Pacific extensional accretionary orogen is signaled by a major episode of oceanic basin formation that followed widespread continental rift-related magmatism (Bryan et al., 1997; Crawford et al., 2003; Schellart et al., 2006). As this first episode of continent margin extension is coeval with the ca. $96 \mathrm{Ma}$ zircon population and the ca. 92 Ma oceanic crust of ophiolite basement on Guadalcanal, we suggest these represent a similar history preserved in the SIA. Although an exotic pre-Eocene arc (Yan and Kroenke, 1993) cannot be entirely discounted, it seems probable that the SIA ophiolite crust was formed in a Cretaceous back-arc basin setting as a result of Pacific slab rollback at the continent margin (e.g., Schellart et al., 2006; Fig. 3).

The Jajao suite provides the earliest evidence of arc rocks (Tejada et al., 1996); this correlates with the 71-63 Ma zircons, and indicates arc activity preceding the opening of the Coral Sea basin. Spreading in the Coral Sea at 62-52 Ma was induced by a short-lived episode of northeast-dipping subduction at the Pocklington Trough (Whattam et al., 2008; Fig. 3). Assuming that sediments bearing continental zircon were unable to travel across basins and bathymetric ridges to the SIA, the source of continentally derived zircons imparted to the SIA must have been deposited before the opening of the Coral Sea. Deposition upon the ca. $92 \mathrm{Ma}$ ophiolite crust cannot be ruled out if the early arc rifted from East Gondwana, but as no terrigenous sediments have been observed above ophiolite pillow lavas (Hackman, 1980), a cryptic source below the ophiolite is probable.

Ophiolite emplacement along strike of the SIA (Fig. 3; Fig. DR2) resulted from micro- continental fragments underthrusting shortlived east-northeast-dipping subduction zones (Whattam et al., 2008). The Eocene onset of ophiolite deformation on Guadalcanal (Hackman, 1980) correlates with the termination of spreading in the Coral Sea and of northeast subduction at the Pocklington Trough (Fig. 2), suggesting that a similar event occurred at the SIA at this time. Hall (2002) predicted Eocene interaction of the SIA with the continent margin. The Louisiade Plateau was likely rifted from the continental shelf by Coral Sea spreading (Fig. 3; Gaina et al., 1999), and its overlying sediments are comparable with those of the Queensland Plateau (Taylor and Falvey, 1977). Thus, partial subduction of the Louisiade Plateau at the Pocklington Trough is a plausible mechanism for triggering ophiolite emplacement and transferring continentally derived zircons into the SIA (Fig. 3).

Tectonic reorganization and reinitiation of Pacific plate subduction (Hall, 2002) preceded late Eocene arc magmatism and ca. 39-33 Ma zircon ages. Opening of the Solomon Sea backarc basin during a further phase of Pacific slab rollback that ensued (Schellart et al., 2006) isolated the SIA from the Louisiade Plateau (Fig. 3). Back-arc spreading continued until the probable $26 \mathrm{Ma}$ arrival of the Ontong Java Plateau at the Vitiaz Trench (Knesel et al., 2008), with recycling of hybrid arc crust into the Umasani intrusions occurring shortly after. 


\section{IMPLICATIONS OF CONTINENTALLY DERIVED ZIRCON IN IOAs}

Our reconstruction provides one possibility of how the episodic slab rollback-controlled extension of a continental margin may generate a diverse geochronological record within IOA crust. The formation of oceanic basins, microcontinental blocks, and arcs contributes to a composite, temporally diverse crust across a retreating extensional accretionary orogen. The zircon components of the extended continent margin, including the geochronological record of continental material, can be recycled within younger arcs by the tectono-magmatic processes that act to transfer the arcs into intra-oceanic settings, thousands of kilometers away from their initial position. Cycles of erosion, deposition, and interaction with younger magmas, after xenocrysts are conveyed to the arc's upper crust, would create a crustal veneer of continentally derived zircon throughout IOA assemblages, albeit with an ever-diluting continental signature. We therefore suggest that arcs formed in extensional accretionary orogens may be predisposed to recycling of continentally derived zircon; as such, the presence of enigmatic xenocrysts within ancient accreted IOAs may be an indicator of arc evolution within this setting.

Regardless of the mechanism by which zircons were incorporated into the SIA crust, their presence demonstrates a dynamic spectrum of arc formation between continental arc and IOA end members. In addition, arc systems with IOA characteristics can be active sites for the mixing of juvenile arc and mature continental material long after a proximal relationship is shared. This highlights the caution with which zircon ages should be used as a provenance indicator within accreted allochthonous IOA terranes.

\section{ACKNOWLEDGMENTS}

Tapster thanks the University of Leicester and British Geological Survey University Funding Initiative Ph.D. studentship (S176), NIGFSC (IP-1212-1110), and SEG Newmont Student Research grant (2274). We appreciate field support provided by the Solomon Islands Geological Survey, Newmont Mining, Sol Gold, and the Tamboko community. Guidance from S.R. Noble and D.J. Smith, and reviews by J. Encarnacion, W. Schellart, and S. Whattam, have improved this manuscript greatly. Tapster, Roberts, and Naden publish with the permission of the Executive Director, British Geological Survey (NERC).

\section{REFERENCES CITED}

Adams, C., Cluzel, D., and Griffin, W., 2009, Detritalzircon ages and geochemistry of sedimentary rocks in basement Mesozoic terranes and their cover rocks in New Caledonia, and provenances at the Eastern Gondwanaland margin: Austra- lian Journal of Earth Sciences, v. 56, p. 10231047, doi:10.1080/08120090903246162.

Baldwin, S.L., and Ireland, T.R., 1995, A tale of two eras: Pliocene-Pleistocene unroofing of Cenozoic and late Archean zircons from active metamorphic core complexes, Solomon Sea, Papua New Guinea: Geology, v. 23, p. 1023-1026, doi: 10.1130/0091-7613(1995)023<1023:ATOTEP $>2.3 . \mathrm{CO} ; 2$.

Bryan, S., Constantine, A., Stephens, C., Ewart, A., Schön, R., and Parianos, J., 1997, Early Cretaceous volcano-sedimentary successions along the eastern Australian continental margin: Implications for the break-up of eastern Gondwana: Earth and Planetary Science Letters, v. 153 , p. 85-102, doi:10.1016/S0012-821X(97)00124-6.

Chivas, A.R., and McDougall, I., 1978, Geochronology of Koloula porphyry copper prospect, Guadalcanal, Solomon Islands: Economic Geology and the Bulletin of the Society of Economic Geologists, v. 73, p. 678-689, doi:10.2113 /gsecongeo.73.5.678.

Collins, W., 2002, Nature of extensional accretionary orogens: Tectonics, v. 21 , no. 4, p. 6-1-6-12, doi:10.1029/2000TC001272.

Condie, K.C., and Kröner, A., 2013, The building blocks of continental crust: Evidence for a major change in the tectonic setting of continental growth at the end of the Archean: Gondwana Research, v. 23 , p. 394-402, doi:10.1016 /j.gr.2011.09.011.

Crawford, A., Meffre, S., and Symonds, P., 2003, 120 to $0 \mathrm{Ma}$ tectonic evolution of the southwest Pacific and analogous geological evolution of the 600 to 220 Ma Tasman Fold Belt System, in Hills, R.R., and Müller R.D., eds., Evolution and dynamics of the Australian Plate: Geological Society of Australia Special Publication 22, p. 377-397.

Gaina, C., Muller, R., Royer, J., and Symonds, P., 1999, Evolution of the Louisiade triple junction: Journal of Geophysical Research, v. 104, p. 12,927-12,939, doi:10.1029/1999JB900038.

Hackman, B.D., 1980, The Geology of Guadalcanal, Solomon Islands: Overseas Memoirs of Her Majesty's Stationery Office, v. 6, 115 p.

Hall, R., 2002, Cenozoic geological and plate tectonic evolution of SE Asia and the SW Pacific: Computer-based reconstructions, model and animations: Journal of Asian Earth Sciences, v. 20, p. 353-431, doi:10.1016/S1367-9120(01) 00069-4.

Hargrove, U.S., Stern, R., Kimura, J.I., Manton, W., and Johnson, P., 2006, How juvenile is the Arabian-Nubian Shield? Evidence from Nd isotopes and pre-Neoproterozoic inherited zircon in the Bi'r Umq suture zone, Saudi Arabia: Earth and Planetary Science Letters, v. 252, p. 308-326, doi:10.1016/j.eps1.2006.10.002.

Joshima, M., Okuda, Y., Murakami, F., Kishimoto, K., and Honza, E., 1986, Age of the Solomon Sea Basin from magnetic lineations: GeoMarine Letters, v. 6, p. 229-234, doi:10.1007 /BF02239584.

Knesel, K.M., Cohen, B.E., Vasconcelos, P.M., and Thiede, D.S., 2008, Rapid change in drift of the Australian plate records collision with Ontong Java plateau: Nature, v. 454, p. 754-757, doi: 10.1038/nature07138.
Kröner, A., 2010, The role of geochronology in understanding continental evolution, in Kusky, T.M., Zhai, M.-G., and Xiao, W., eds., The Evolving Continents: Understanding Processes of Continental Growth: Geological Society of London Special Publication 338, p. 179-196, doi:10.1144/SP338.9.

Miura, S., Suyehiro, K., Shinohara, M., Takahashi, N., Araki, E., and Taira, A., 2004, Seismological structure and implications of collision between the Ontong Java Plateau and Solomon Island Arc from ocean bottom seismometerairgun data: Tectonophysics, v. 389, p. 191220, doi:10.1016/j.tecto.2003.09.029.

Neef, G., and McDougall, I., 1976, Potassium-argon ages on rocks from Small Nggela Island, British Solomon Islands, SW Pacific: Pacific Geology, v. 11, p. 81-86.

Nicholson, K., Maurizot, P., Black, P.M., Picard, C., Simonetti, A., Stewart, A., and Alexander, A., 2011, Geochemistry and age of the Nouméa Basin lavas, New Caledonia: Evidence for Cretaceous subduction beneath the eastern Gondwana margin: Lithos, v. 125 , p. 659-674, doi: 10.1016/j.lithos.2011.03.018.

Petterson, M.G., et al., 1999, Geological-tectonic framework of Solomon Islands, SW Pacific: Crustal accretion and growth within an intraoceanic setting: Tectonophysics, v. 301, p. 35-60, doi:10.1016/S0040-1951(98)00214-5.

Schellart, W.P., Lister, G.S., and Toy, V.G., 2006, A Late Cretaceous and Cenozoic reconstruction of the Southwest Pacific region: Tectonics controlled by subduction and slab rollback processes: Earth-Science Reviews, v. 76, p. 191233, doi:10.1016/j.earscirev.2006.01.002.

Taylor, L., and Falvey, D., 1977, Queensland Plateau and Coral Sea Basin: Stratigraphy, structure and tectonics: APEA Journal, v. 17, p. 13-29.

Tejada, M., Mahoney, J., Duncan, R., and Hawkins, M., 1996, Age and geochemistry of basement and alkalic rocks of Malaita and Santa Isabel, Solomon Islands, southern margin of Ontong Java Plateau: Journal of Petrology, v. 37, p. 361-394, doi:10.1093/petrology/37.2.361.

Whattam, S.A., Malpas, J., Ali, J.R., and Smith, I.E.M., 2008, New SW Pacific tectonic model: Cyclical intraoceanic magmatic arc construction and near-coeval emplacement along the Australia-Pacific margin in the Cenozoic: Geochemistry Geophysics Geosystems, v. 9, Q03021, doi: 10.1029/2007GC001710.

Yan, C., and Kroenke, L., 1993, A plate tectonic reconstruction of the Southwest Pacific, 0-100 $\mathrm{Ma}$, in Berger, W.H., et al., eds., Proceedings of the Ocean Drilling Program, Scientific Results, Volume 130: College Station, Texas, Ocean Drilling Program, p. 697-709.

Zirakparvar, N., Baldwin, S., and Vervoort, J., 2013, The origin and geochemical evolution of the Woodlark Rift of Papua New Guinea: Gondwana Research, v. 23, p. 931-943, doi:10.1016 j.gr.2012.06.013.

Manuscript received 29 June 2014

Revised manuscript received 24 September 2014

Manuscript accepted 25 September 2014

Printed in USA 